\title{
A voz e vez dos barqueiros: um diálogo crítico de reinvenção freireana frente aos desafios da atualidade
}

\author{
The voice and turn of boatmen: a critical dialogue of Freirean \\ reinvention in face of today's challenges
}

\section{La voz y el turno de los barqueros: Un diálogo crítico de la reinvención freireana ante los desafíos de la atualidad}

\author{
Mariana Parise Brandalise Dalsotto' \\ https://orcid.org/0000-0003-4926-6320
}

César Augusto Rossatto²

https://orcid.org/ 0000-000 I-9063-I575

O texto que aqui se desenvolveu, tinha como proposta inicial a realização de uma entrevista com o professor doutor César Augusto Rossatto que relacionasse sua trajetória de estudos com a vida e obra de Paulo Freire. Sendo coerente com o pensamento freireano, especialmente no que se refere ao conceito de diálogo, à ideia de horizontalidade nas relações e à ideia de que não há saber mais ou saber menos, mas sim, saberes diferentes (FREIRE, 2005), o professor fez uma contraproposta, convidando para que fizéssemos um diálogo, o qual gerou a produção aqui transcrita. O diálogo é um conceito importante para Paulo Freire e o próprio educador organizou diversos livros com outros colaboradores, usando este formato 3 , o que também justifica essa nossa escrita dialogal.

Tendo nascido em Tangará, Santa Catarina, Brasil, César Augusto Rossatto vive nos Estados Unidos desde 1984, mas suas relações com o país de origem perpassam toda a sua vida e sua atividade

\footnotetext{
' Doutoranda em educação pela Universidade de Caxias do Sul. Bolsista PROSUC/CAPES. mpbrandalise@ucs.br

${ }^{2}$ Doutor em Pedagogia Crítica. Professor Associado na Universidade do Texas El Paso. crossatto@utep.edu

${ }^{3}$ Alguns exemplos de livros de Paulo Freire em diálogo com outros autores são: Por uma Pedagogia da Pergunta; Essa Escola Chamada Vida; Medo e Ousadia: o Cotidiano do Professor; Pedagogia: Diálogo e Conflito; Sobre Educação; Aprendendo a Própria História; Teoria e Prática em Educação Popular; Alfabetização: Leitura do Mundo, Leitura da Palavra.
}

Olhar de professor, Ponta Grossa, v. 24, p. I-22, e-167I9.012, 2021.

Disponível em <https://revistas2.uepg.br/index.php/olhardeprofessor> 
A voz e vez dos barqueiros: Um diálogo crítico de reinvenção freireana frente aos desafios da atualidade acadêmica. Por conta disso, relações entre Brasil e Estados Unidos aparecem ao longo de todo o diálogo, tendo em vista que o professor trouxe elementos de sua própria vivência, que entrelaça as realidades dos dois países. $O$ professor é graduado em Teologia e em Filosofia na Universidade de Moema, São Paulo, mestre em administração escolar pela Universidade do Estado da Califórnia, Los Angeles e Doutor em Pedagogia Crítica pela Universidade da Califórnia, Los Angeles (UCLA).

Atualmente é professor associado na Universidade do Texas, El Paso (UTEP) e um dos líderes e diretores da unidade de Fundamentos socioculturais da Educação, do departamento de formação de professores. É Cônsul Honorário Brasileiro e autor de diversos livros e artigos publicados nos EUA e mundo afora, incluindo The Freirean Legacy: Educating for Social Justice (2002), Engaging Paulo Freire's Pedagogy of Possibility: From Blind to Transformative Optimism (2005), Reinventing Critical Pedagogy: Widening the Circle of Anti-Oppression Education (2006) e, em português, Reinventar a Pedagogia Crítica (2005), entre outros publicados individualmente e em parceria com professores distintos, sobre diversas temáticas da área da educação.

Já Mariana Parise Brandalise Dalsotto é doutoranda no Programa de Pós-Graduação em Educação da Universidade de Caxias do Sul, Rio Grande do Sul. É bolsista da Coordenação de Aperfeiçoamento de Pessoal em nível Superior (CAPES) e foi Visiting Graduate Researcher na Universidade da Califórnia, Los Angeles (UCLA), com bolsa do Programa de Doutorado Sanduíche no Exterior (PDSE) também da CAPES. É mestre em educação e graduada em Pedagogia. Sua pesquisa atual está situada no campo da História da Educação e versa sobre os círculos de cultura a partir dos quais era realizado o programa de alfabetização proposto por Paulo Freire nos anos 1960.

O caminho consagrado de um professor universitário cruzou-se com o caminho de formação acadêmica em andamento de uma doutoranda e resultou no diálogo aqui transcrito. Com sua vasta experiência, o professor César abordou as temáticas selecionadas de forma mais densa e expressiva, como era a ideia inicial, mas abriu espaços para interações e troca de reflexões.

Metaforicamente e poeticamente mencionamos aos Barqueiros, neste diálogo, referindo-nos às populações que historicamente vivem em esferas e espaços liminares, que são tomados como invisíveis e sem voz, mas que carregam consigo o potencial de serem agentes históricos que facilitam o inédito viável. Esta metáfora deriva-se de uma pequena anedota contada durante nosso diálogo.

Mariana Parise Brandalise Dalsotto: Gostaria que iniciássemos conversando sobre qual é a importância histórica de Paulo Freire para a educação e qual é a importância do pensamento dele para os processos educativos emancipatórios na atualidade. Freire tem inúmeras contribuições para a educação, mas se nós pudéssemos enumerar algumas, quais seriam?

César Augusto Rossatto: Primeiro temos que dar o respeito merecido a Paulo Freire por ter rompido barreiras, ter sido pioneiro no programa de alfabetização no Brasil e depois mundo afora.

Olhar de professor, Ponta Grossa, v. 24, p. 1-22, e-16719.012, 2021.

Disponível em <https://revistas2.uepg.br/index.php/olhardeprofessor> 
Naquela época, nos anos 1960 se tomavam anos para os adultos aprenderem a ler e escrever, usando os métodos que as crianças usavam, memorizando o alfabeto. Então Paulo Freire descobriu um método que ao invés de anos, seria possível alfabetizar em dois meses. Mas, antes de falar do programa de alfabetização gostaria de dar uns passos para trás e falar um pouco de Paulo Freire como criança. Ele foi filho de um policial militar e seu pai faleceu quando Freire tinha 13 anos de idade. Também acho importante falar que amigos e familiares de Freire depois o levaram para uma escola particular, onde a Nita Freire (Ana Maria Araújo Freire) - que foi minha professora - e o pai dela, foram fundamentais auxiliando Freire a ter acesso a essa educação. Ele se formou advogado, mas não exerceu, e resolveu estudar filosofia da educação.

O que eu acho genuíno e único foi a capacidade de Paulo Freire conectar a experiência pessoal com os estudantes adultos. Paulo Freire, quando criança, aprendeu a ler e escrever praticamente sozinho com palavras que ele tinha curiosidade. Uma criança o que vê? Ela vê a palavra 'Coca-Cola' escrito. Tem gente que diz 'ah, a criança já sabe ler', mas não. É possível fazer a leitura da imagem. Paulo Freire pedia para mãe escrever na areia, no quintal da casa, ao pé de um mangue - mais tarde ele escreveu sobre isso também ${ }^{4}$ - e ele escrevia na areia, com a ajuda da mãe. Ele depois trabalhou com a alfabetização de adultos e ficou famoso. O Brasil, naquela época tinha grande parcela da população analfabeta. Já imaginou o atraso? Hoje a sociedade não comporta mais uma população que não tenha acesso à uma educação de qualidade. Hoje é bem claro que a qualidade da democracia se respalda na qualidade de educação que as pessoas têm. Eu cheguei a publicar sobre isso ${ }^{5}$.

Freire, ao ensinar adultos, se deu conta de que eles tinham um universo vocabular mais denso e já tinham distintas profissões. Ele percebeu que a realidade do sul do Brasil desenhava o currículo da educação de adultos a nível nacional e tinha, por exemplo, a palavra uva. Eu, filho de italianos conheço bem a uva, a gente fazia vinho em família. Na minha região a uva era importante, estava enraizada na fibra social. Mas não fazia sentido para quem não sabia o que era uva ou conhecia outras frutas que o sul não tinha. E esse currículo se fazia opressor, descontextualizado. Então Paulo Freire lembrou da experiência dele como criança e começou a usar palavras com as quais os alunos eram familiarizados. A partir daquelas palavras ele separava em sílabas, decodificava as letras e com as letras da primeira palavra formava novas palavras. Esse foi um presente mágico que Paulo Freire nos deixou. Só por isso devemos estar extremamente gratos a ele.

\footnotetext{
${ }^{4}$ FREIRE (200I).

${ }^{5}$ Muller; Rossatto (2016). 
A voz e vez dos barqueiros: Um diálogo crítico de reinvenção freireana frente aos desafios da atualidade

Freire também escreveu o livro Reading the word and the world 6 . E ele percebeu que não vamos à escola para aprender a memorizar, mas temos de aprender a pensar criticamente, aprender o significado da palavra dentro do contexto em que vivemos, aprender a ser sujeitos de nossa própria história, de nossa própria aprendizagem, aprender a ter voz. Naquela época, quem era analfabeto não poderia votar ${ }^{7}$, então grande parte da população brasileira não tinha nenhum representante que falasse e defendesse as experiências e interesses deles. E, ao aprender a ler e escrever, as pessoas passaram a questionar suas realidades. Antes eram dóceis e obedientes e depois começaram a fazer perguntas, queriam ser prefeitos de suas cidades, vereadores, líderes comunitários. Queriam participar nas decisões de sua realidade.

Paulo Freire chegou a trabalhar com o Ministério da Educação e Cultura do Brasil, mas quando os militares entraram no poder, acharam que o trabalho dele era subversivo e, automaticamente, foi rotulado como comunista. Ele incomodou os militares, porque no regime militar você não questiona a autoridade, você obedece a autoridade. Por isso, o trabalho de Freire era problemático para a elite brasileira e para as autoridades que levaram a ditadura militar ao Brasil. Mas essa foi uma contribuição que Freire fez primeiro ao Brasil e depois levou ao mundo todo: a alfabetização de adultos de forma rápida, libertadora e emancipadora.

E não parou aí. No Chile ele fez o mesmo projeto e, ainda, escreveu o livro Pedagogia do oprimido (FREIRE, 2005). E precisamos falar que Freire estava chateado quando o escreveu porque a classe dominante no Brasil não queria que as pessoas aprendessem a ler e a escrever, que saíssem de seu posicionamento de subalternidade. Depois que escreveu Pedagogia do Oprimido, Harvard o contratou. Freire passou seis meses aqui nos Estados Unidos e depois foi para a Suíça, onde participou dos programas do Conselho Mundial de Igrejas, a nível internacional, e levou esses programas para a África, a América Latina, etc. Considero Pedagogia do Oprimido como um segundo presente que Freire nos deixou. É um livro consagrado, clássico, que perpassa o tempo, não morre, não deixa de ser atual. Freire recebeu muitos prêmios a partir do livro, foi cidadão honorário de muitos lugares do mundo e ganhou o Prêmio UNESCO da Educação para a Paz, no ano de 1986.

Depois, voltou ao Brasil e foi secretário de educação da cidade de São Paulo, quando ele também deixou seu terceiro presente: um programa interdisciplinar no mandato da Luiza Erundina como prefeita da cidade de São Paulo. Nesse período, Freire também escreveu o livro Educação na cidade. Eu mesmo fui pessoalmente estudar os trabalhos dele em São Paulo e visitei as escolas.

\footnotetext{
${ }^{6}$ Em português: FREIRE; MACEDO (1994).

${ }^{7} \mathrm{O}$ voto de analfabetos somente foi permitido a partir da Emenda Constitucional $\mathrm{n}^{\circ} 25$ de 15 de maio de 1985 , segundo informação disponível em https:/www.tse.jus.br/imprensa/noticias-tse/2016/Novembro/constituicaode-1985-garantiu-o-direito-ao-voto-aos-eleitores-analfabetos.
}

Olhar de professor, Ponta Grossa, v. 24, p. I-22, e-16719.012, 2021.

Disponível em <https://revistas2.uepg.br/index.php/olhardeprofessor> 
Inicialmente, Freire deu um aumento aos salários dos professores e reformou as escolas. Depois, convidou as pessoas para fazerem o único programa democrático de educação que eu conheço. Nos Estados Unidos, nunca houve uma reforma educacional democrática. Todos os programas de educação vêm de cima para baixo, por mandatos dos governos federal, estadual, distrital ou do sistema judiciário que determinam os processos que influenciam a educação. Nunca houve uma educação de baixo para cima - apesar de Paulo Freire citar John Dewey, que ajudou a definir o programa democrático aqui nos Estados Unidos e a construir a identidade da democracia.

Esse modelo de reforma democrática no ensino público seria, então, o terceiro presente que Paulo Freire deixou ao Brasil e ao mundo, uma vez que ele publicou sobre isso. É uma ideia de como fazer uma educação democrática, verdadeiramente. Ele ia nas favelas, nas escolas e convidava os que tinham interesse: pais, alunos, professores, administradores, líderes comunitários. Todos participavam da formação de uma temática geradora, com a qual os professores iriam trabalhar de forma interdisciplinar. Outra coisa fantástica, emancipatória, libertadora, foi o fato de que os temas que saíam das favelas, por exemplo eram: lixo, grafite, drogas, falta de saneamento, etc. E os professores, com esses temas, trabalhavam linguagem, matemática, biologia, química... de forma interdisciplinar. Com o tema lixo, por exemplo, as crianças aprendiam a reciclar, os pais aprendiam a trabalhar com isso e era possível notar uma transformação na comunidade que ficava mais limpa e saudável. E o que é mais importante do que isso: ver o trabalho de uma sala de aula ter um efeito, a nível local, transformador. Isso me emociona, eu acho fantástico e algumas dessas ideias foram utilizadas nos Estados Unidos.

Paulo Freire também influenciou a educação de crianças na Bahia, no Projeto Axé, por exemplo. Inclusive, Nita Freire comentou comigo que ela e Freire foram ajudar na formação dos professores, que aprendiam o "Método Paulo Freire" - que, inclusive, ele nunca chamou de seu método - aprendiam na rua a conhecer o universo vocabular das crianças. Só o fato de ficarem entre quatro paredes exigia uma disciplina, por isso, as crianças viam a escola como uma ameaça. Mas, com o projeto, as crianças iam para a escola porque era alegre, elas tocavam tambor, faziam field trips [viagens de campo], etc. Eu cheguei a visitar o Projeto Axé algumas vezes e vi que ali as crianças aprendiam a escrever sua própria história e a defender seus direitos. Aprendiam cidadania e a se integrar à sociedade como cidadãos dignos. Esse programa foi tão bem-sucedido que depois, se tornou uma referência internacional.

Os jornais London Times, New York Times, Washington Post, LA Times, por exemplo, publicaram o sucesso desse programa. Você via o teatro que as crianças faziam, representando suas experiências como seres históricos. Inclusive, algumas dessas crianças vieram a Nova lorque apresentar o teatro e foi um grande sucesso. Além disso, o orçamento participativo, que iniciou em Porto Alegre, tem muito de Paulo Freire e esse projeto se espalhou pelo Brasil afora. A comunidade participa das 
A voz e vez dos barqueiros: Um diálogo crítico de reinvenção freireana frente aos desafios da atualidade decisões de gastos dos recursos da cidade, não sendo o prefeito que decide arbitrariamente. Inclusive, eu estive na Austrália dando uma conferência e me convidaram para falar sobre o orçamento participativo de Porto Alegre, virou uma referência internacional entre líderes sindicais e ativistas sociais.

Por último, gostaria de falar de outro presente que nos deixou Paulo Freire, inicialmente com Pedagogia do Oprimido e depois em outros livros: o fato de que ele conseguiu definir a educação colonizadora, a educação opressora. Ele falou que ninguém tem o direito de fazer uma crítica às políticas sociais a menos que seja capaz de oferecer uma outra possibilidade de viver. Paulo Freire foi capaz de definir o que é uma educação autoritária e conservadora e falava que a educação de memorização era uma educação bancária. Ele disse certa vez que não era contra a memorização, se as pessoas aprendem memorizando, para ele estava tudo bem, apenas essa não poderia ser a única maneira de aprender (ROSSATTO, 2005).

Mas seria muito ingênuo nós pensarmos que as classes dominantes dariam às classes populares uma educação libertadora onde elas pudessem ver como sua força de trabalho é usada e como a classe dominante se aproveita da classe dominada e quer mantê-la obediente. Freire desconstruiu a educação tendenciosa, que tinha uma malícia política que favorecia as classes dominantes; que era uma educação autoritária, sem espaço para o diálogo, sem espaço para se reinventar; que era de assimilação, de opressão; que não ajudava as crianças a valorizarem sua própria forma de identidade, pois só recebiam o conhecimento. Uma educação da alienação, da domesticação, da manipulação... Quer dizer, a criança saía da escola como objeto da história e se mantinha o status quo. Esta era, de fato, uma educação desumanizadora. E em Freire você tem uma crítica radical a essa maneira de pensar a educação. Com tudo isso, ele ofereceu, então o que eu acho uma contribuição fantástica. As pessoas que estão propagando o discurso de ódio contra ele são injustas, porque ele defendeu uma educação democrática e crítica, que começa a partir do universo dos educandos, com o qual eles podem se conectar, se identificar e se ver como agentes centrais dessa educação.

Mariana: E ao mesmo tempo essa educação deixa de apenas reproduzir a realidade dos educandos e busca justamente a problematização dessa realidade, busca fazer uma crítica a ela com o objetivo de transformá-la...

César: Isso. E assim o aluno aprende em uma educação na qual ele tem acesso ao que também Ihe interessa e não só ao que interessa aos políticos poderosos que definem os currículos e as políticas educacionais. Então, você tem razão, Mariana, essa educação de fato abre espaço para um diálogo onde o aluno tem direito de participar de forma democrática. Paulo Freire ofereceu uma educação dialética, que não deve ser vista só de forma institucionalizada e burocratizada, que não deve ser só baseada no estudo com os livros de gerações anteriores. Temos de nos ver como agentes que vão levar os

Olhar de professor, Ponta Grossa, v. 24, p. 1-22, e-16719.012, 2021.

Disponível em <https://revistas2.uepg.br/index.php/olhardeprofessor> 
conhecimentos das gerações anteriores a passos à frente. A educação tem que ter um cunho dialético e dinâmico e se reinventar constantemente.

Eu tive a oportunidade de entrevistar Paulo Freire, a esposa dele foi minha professora em São Paulo e eu aprendi com eles uma diferente versão da história brasileira. Eu vi em Paulo Freire a possibilidade de autotransformação e autolibertação. Eu sou filho de agricultores, estudei para padre e me via limitado no Brasil com a ditadura militar. Quando me foi apresentado o pensamento freireano, esse me tocou a fundo. Eu não seria quem eu sou hoje, segundo o curso normal da história, eu me transformei usando o pensamento de Paulo Freire e vi nele a libertação intelectual. Ele chegou a falar, a partir da influência de Erich Fromm, que as pessoas têm medo de sua própria libertação; a partir de Albert Memmi, sobre o colonizador e colonizado; e outros, como Hegel, Karl Marx, Anísio Teixeira, John Dewey, Frantz Fanon, Antonio Gramsci... Eu cheguei a conhecer a teoria do construtivismo, na qual você começa no universo de conhecimento da criança, do dia-a-dia e o bom professor trabalha com a curiosidade, com o conhecimento dos alunos e vai os ajudando a contemplar novos horizontes. Essa educação é emancipadora e o aluno não vai para escola para absorver, mas sim, para produzir conhecimentos. E o que há de mais poderoso do que isso? Esse é outro dos grandes presentes de Paulo Freire: a ideia de conscientização.

Mas, voltando à entrevista que eu fiz com Freire, eu cheguei a fazer a pergunta: 'o que é a conscientização?' Eu falei que era consciência mais ação e ele concordou. Depois perguntei 'o que o senhor gostaria de ver nos que seguiram as suas teorias?' E ele falou 'Não me copiem, me reinventem'. Então eu sinto que esse é o chamado que ele nos deixou. Ele influenciou a pedagogia crítica, desenvolveu uma nova pedagogia. Por isso, o mundo todo é agradecido a Paulo Freire, o mundo todo lê Paulo Freire. Nos Estados Unidos ele está entre os 100 mais lidos e é extremamente respeitado. Obviamente, alguns dizem que a leitura não é fácil. Entendo que ele escreveu a Pedagogia do Oprimido para a classe acadêmica, mas ele também escreveu outros livros que são de acesso mais fácil, tempos depois. Com tudo isso, o resultado é que as pessoas conseguem se ver como sujeitos de sua própria história, que lutam por igualdade social, por libertação, o que é humanizante e transformador.

Paulo Freire falou que os oprimidos acabam deixando de exercer sua vocação ontológica de ser humano e, assim, o opressor não consegue ver que explora os outros, porque ele também perde sua humanidade. Paulo Freire deixou essa mensagem. Ele lutava por um mundo que fosse menos feio, mais humano, mais ético, onde as pessoas aprendem a ser elas mesmas e aprendem a amar. Porque, quando há esse crescimento da cultura do ódio e do medo, as pessoas não são felizes, o mundo se torna triste e feio.

Mariana: Concordo, professor César, com as grandes contribuições que você enumerou. E com a característica de que elas podem se retraduzir, se reinventar a partir de nossas práticas. Em 
A voz e vez dos barqueiros: Um diálogo crítico de reinvenção freireana frente aos desafios da atualidade síntese, as contribuições que você explicitou seriam: a proposta de educação de adultos, no início dos anos 1960; o livro Pedagogia do Oprimido onde ele sistematizou também suas ideias e pode expô-las ao mundo inteiro; a sua prática como secretário de educação na volta ao Brasil, desenvolvendo um programa interdisciplinar e democrático; sua concepção de educação libertadora, que fazia uma crítica à educação colonizadora, domesticadora, opressora; e a ideia de conscientização.

Entendo que a importância histórica de Paulo Freire está também em suas reflexões sobre a educação, em especial, na questão da educação libertadora, conscientizadora e humanizadora (que remete para a importância do educador não só para a educação, mas para a formação humana, como um todo). O legado de Paulo Freire está também em suas práticas em prol da educação, nas diferentes instâncias as quais você mesmo trouxe: a alfabetização de adultos nos anos 1960, seu trabalho em outros países e a culminância na volta ao Brasil, na prefeitura de São Paulo, bem como em sua prática de escrita.

E a relevância do pensamento dele para os processos educativos emancipatórios na atualidade se dá a partir desse legado de reflexões que trouxeram contribuições importantes e especialmente do desejo de ser reinventado. Freire fez uma primeira reflexão, que foi muito importante para o repensar dos processos educativos no período histórico no qual suas ideias foram desenvolvidas, e continua sendo no presente, tendo em vista que suas ideias ainda não foram superadas, ultrapassadas. Ele foi importante também para o advento da Educação Popular na América Latina. E admiro o fato de que Freire sempre colocou suas reflexões em aberto para que elas pudessem ser levadas adiante e atualizadas para realidades diferentes das que ele vivenciou. As realidades atuais vivem outras situações, outros problemas, mas podem refletir levando em consideração o pensamento freireano.

César: Falando da realidade que eu vejo há mais de 20 anos como professor universitário nos Estados Unidos, quando a gente fala de Paulo Freire, todos querem se identificar com o oprimido e ninguém quer se ver como opressor. E eu vejo que precisamos reinventar Freire olhando desse lado: quem são os oprimidos e quem são os opressores?

E eu acho importante também falarmos das críticas a Paulo Freire: uma das primeiras que realmente $\circ$ afetou foi o discurso das feministas aqui nos Estados Unidos. Elas acharam que ele não tinha feito a crítica do discurso patriarcal. Toda nossa educação é patriarcal, colonizadora, europeia, do globo norte. Paulo Freire, no final de sua vida, conseguiu fazer algumas reparações na linguagem, mas não foi suficiente. E hoje já se fala abertamente que a hegemonia do patriarcalismo é um grande fator de opressão. O Brasil, por exemplo, hoje é o segundo país com maior número de feminicídio (depois do México) e isso é o resultado de um abuso masculino que, muitas vezes já está internalizado também nas mulheres. E outra hegemonia é a branquitude, a supremacia branca. A gente precisa falar disso. Esses temas não foram abordados por Freire profundamente, apesar de ele ter falado sobre 
“qualquer tipo de opressão". A gente precisa "dar nome aos bois”, doa a quem doer. Certa vez, eu estava dando uma conferência na África do Sul, me convidaram para falar sobre a branquitude, as teorias críticas raciais para professores universitários e, depois de uma hora falando de Freire, quando comecei a falar da branquitude os professores brancos começaram a sair e alguns negros também. Isso deixou bem claro a necessidade de dar nome aos sistemas opressores.

É por isso que esses sistemas neofascistas no Brasil de caquistocracia, de autocracia, de autoritarismo, de governos mal preparados atacam a nossa comunidade acadêmica porque somos nós que ajudamos a abrir os olhos, a criar consciência sobre os problemas que nos afetam. Você sabe que sou cônsul brasileiro aqui na fronteira americana e só o ano passado 22 mil brasileiros cruzaram a fronteira. São sinais de insatisfação da geopolítica, de programas sociais e econômicos, da falta de oportunidade para o povo participar e ter uma vida de dignidade. E eu vejo bem claro isso nos países capitalistas. Por exemplo: os Estados Unidos são o ventre do capitalismo, desse sistema onde a classe dominante, as elites não pagam imposto, com a ilusão de que você ajudar os ricos vai abrir mais oportunidade de trabalho. Uma grande ilusão de trickledown theory, uma mentira. Eu defendo esses programas sociais que ajudam as pessoas que vivem no liminal space, como Peter McLaren usava. Quando você traz as pessoas que vivem no mundo marginalizado para o mainstream, para o centro, não só elas produzem mais, como elas também contribuem para a circulação do capital. Quando você ajuda essas classes a ter acesso à melhor educação, trabalho, saúde, elas produzem mais. Se você ganha mais, você também faz um maior progresso. Querer manter a população subalternizada e escravizada mantém a mentalidade do século passado, da idade da escravidão.

Mariana: Pensando nessa relação que você vai fazendo com aspectos da realidade atual brasileira, especialmente nos últimos anos, neste contexto social e político surgiram muitos discursos contrários (e, com eles, discursos favoráveis) a respeito de Paulo Freire. Suas ideias são atacadas e parece haver uma espécie de "exílio póstumo e intelectual" do educador. Você poderia comentar qual a sua interpretação sobre essas ondas reacionárias, do Brasil?

César: Paulo Freire apoiou os sindicatos dos trabalhadores, movimentos sociais e apoiou a formação do PT. Depois de 13 anos do governo PT no Brasil, se criou uma política de ódio contra o partido que, obviamente, afetou a imagem de Paulo Freire. Mas, nesse momento atual, também nos deparamos à subida do neofascismo através das fake news, acho que ainda tem muita gente que ainda não fez o homework, como dizemos, de estudar o que é fake news. Fake news não é simplesmente propaganda mentirosa, é um programa financiado por investimentos multimilionários com extrema eficácia, tendo como alvo boa parte da população, as pessoas extremamente fanáticas (por religião, por esporte, entre outros). 
A voz e vez dos barqueiros: Um diálogo crítico de reinvenção freireana frente aos desafios da atualidade

Hoje os ricos controlam os sistemas educacionais, instituições sociais, governamentais. Contudo não somente eles têm o controle dos recursos, mas também da mente das pessoas. Vemos isso em épocas de eleições. Nós vivemos numa era da pós verdade, uma era dogmática. Paulo Freire falou claramente, inclusive na entrevista que fiz com ele, que nós podemos ir, de forma casual, de encontro ao nosso interesse de pesquisa, mas, depois, é preciso ter rigor, ver se é verdade ou não, tomando como base a ciência. Então essa cultura das fake news atinge essa população que vive, por exemplo, como vítima dos mercenários da fé e, num segundo grupo, fanáticos de esporte, que levam a ideia das vitórias dos times para as eleições. Por vezes, ficam fora realidade e perdem a noção de humanidade, querem passar por cima dos outros, para ganhar, não importa se violam as "regras do jogo". E tem, ainda, os grupos da teoria da conspiração, bombardeados pela mídia. Vejo que isso ocorre muito no Brasil e nos Estados Unidos.

Quando a gente vive com essa consciência ingênua acabamos sendo vítimas de manipuladores. A saída é o pensamento crítico, é a verdade, é a ciência e a ética. Com isso somos capazes de respeitar a nós mesmos, a nos amarmos, a ter carinho pela vida e a trabalhar para trazer mais vida à sociedade. Mas essa cultura atual é a cultura da morte, vemos claramente no momento da pandemia que existe um interesse em deixar as pessoas morrerem para se aproveitar das riquezas. Aqui nos Estados Unidos é bem claro: querem reabrir as escolas públicas porque as crianças que vão para essas escolas são da população negra, de classe média/trabalhadora ou pobre. É como enviar essas pessoas para o matadouro. E eu vejo que o Brasil copia dos Estados Unidos essa necropolítica, o que é um erro enorme porque o Brasil é um país grande e rico que só precisa organizar como trabalhar sua riqueza, tem todo o potencial de manter e proteger suas riquezas.

Mariana: Você falou de algumas críticas que Paulo Freire recebeu ao longo de sua vida, que ele buscou explicar algumas delas reformulando seu pensamento e se reinventando e, ainda, que ele acabou não tendo tempo de fazer um debate mais aprofundado sobre outras. Outra questão é que ele continua recebendo críticas (positivas e negativas), mesmo após ter falecido, justamente porque seu pensamento continua sendo utilizado para promover reflexões teóricas e práticas para a educação, continuando atual e não sendo superado. E tudo o que é atual recebe críticas. Paulo Freire marcou a história da educação do país, tendo em vista suas contribuições para a educação e também pelo fato de ser reconhecido internacionalmente.

Mas, ao mesmo tempo, a história de Paulo Freire está marcada pelo contexto brasileiro primeiro em função de alguns acontecimentos, mas, especialmente (e mais importante, na minha opinião) porque foi a partir desse contexto que Paulo Freire iniciou suas reflexões sobre a educação. O problema é quando alguns fatos da vida de Freire no Brasil são isolados, descontextualizados e, com isso, aproveitados para atacar seu legado. Isso tem sido feito nos últimos anos, por alguns grupos 
reacionários que, não conhecendo bem quem foi Paulo Freire, não conseguem ter uma compreensão crítica sobre seu pensamento (que pode sim encontrar pontos a serem melhorados e reinventados como ele mesmo pede - mas que também deve considerar o contexto no qual foi tecido, além de reconhecer sua importância e suas contribuições para a educação).

Também entendo que a relação de Paulo Freire com o PT e a estada deste partido na presidência do Brasil por vários anos acabou transferindo críticas às ações do partido para o educador. Esta realidade do contexto político brasileiro foi algo que influenciou muito os movimentos que buscaram atacar Paulo Freire nos últimos anos. Me parece que parte deste movimento tenta expulsar ou exilar o pensamento freireano, tal como aconteceu com o educador em 1964. Parece haver uma onda carregada de discursos ideológicos que busca levar Paulo Freire a um novo exílio, agora intelectual. Esse novo exílio póstumo e intelectual traz à tona, na verdade, a importância de se falar cada vez mais do educador, de estudar seu pensamento, de reinventar suas práticas e reflexões e isso coloca em pauta a atualidade da práxis freiriana. E sua práxis se atualiza na mobilização, na radicalidade reflexiva, na luta em defesa do ser humano, na busca pela transformação da realidade opressora.

Em meio a esses posicionamentos sectários, nós vivemos em um tempo de pandemia, não só do coronavírus, mas também de fake news, outro aspecto que você já comentou. As mídias sociais, digitais têm grande papel na disseminação das ideias que geram esses diferentes posicionamentos, mas atuam a partir de seus interesses e muitas vezes acabam descontextualizando e recortando ideias, disseminando falsas informações. Contra isso, mais uma vez Paulo Freire pode ser uma contribuição, porque ele incentiva a problematização da realidade, a problematização dos conhecimentos que são tomados como verdades e incentiva que façamos uma construção de conhecimentos e não uma simples recepção de informações. Isto se vale tanto para a educação escolar, formal, quanto para a nossa busca diária por informações, que é a educação que ocorre informalmente. Refletindo a partir de Paulo Freire, entendo que precisamos conhecer além do que é divulgado nas mídias, conhecer sobre aquilo que está sendo dito, ler com criticidade e buscar refletir sobre o que se lê, para que se possa concordar ou discordar a partir de um pensamento fundamentado e coerente. Isso é necessário para as notícias cotidianas e também para as opiniões tecidas sobre Paulo Freire, por exemplo.

De qualquer modo, entendo que estamos num contexto que "re-clama" Paulo Freire, que o coloca de novo em debate, que é propício para tecermos reflexões. Este momento pode (e deve) ser tomado como motivação para que os que já conhecem a vida e a obra do educador aprofundem seus conhecimentos e os que não conhecem busquem conhecer, para adensar o debate e se posicionar com propriedade - seja a favor ou contra suas ideias. Este é um tempo que fomenta a reflexão e a construção de novos pontos de vista sobre o educador na atualidade. E nesse contexto, por que ainda Paulo Freire incomoda? 
A voz e vez dos barqueiros: Um diálogo crítico de reinvenção freireana frente aos desafios da atualidade

César: Bom, agradeço a sua resposta, acho que você falou muito bem. Você traz o contexto brasileiro e eu te dou crédito por essa ideia de "exílio póstumo", que é bem sua e verdadeira e merece a nossa atenção. E justo nessa época de pandemia você fala que também há uma pandemia de fake news - que é uma reflexão interessante - e também a importância de problematizarmos a nossa realidade, para que possamos fazer uma construção de conhecimentos e não uma simples recepção de informações. Eu concordo com você. Estamos num contexto que re-clama Paulo Freire e este é um tempo que fomenta a reflexão e a construção de novos pontos de vista sobre ele na nossa atualidade.

E gostaria de resgatar um ponto do histórico de Paulo Freire que já conversamos: ele foi um advogado e não quis exercer a profissão pois logo nos primeiros dias ele percebeu que 'não era para ele'. Aquele conhecimento das leis deve ter acompanhado ele a vida inteira, mas ele se formou como professor e percebeu que como professor ele poderia fazer uma grande diferença no mundo. Assim como eu quando estava estudando para ser padre e saí do seminário porque percebi que como professor eu poderia fazer mais. Por isso também eu só quero trabalhar em universidades públicas e, aqui nos Estados Unidos, temos a Academic Freedom Law, uma lei de liberdade acadêmica e não temos medo de falar o que precisamos. Os educadores precisam se sentir livres para fazer uma aproximação com a verdade e eu sinto que, como educadores, nós podemos mudar o mundo. Como a frase célebre que Freire nos deixou: "A educação não transforma o mundo, a educação transforma as pessoas e as pessoas transformam o mundo".

Lembro, também, que o próprio Paulo Freire contava uma anedota, ou piada: Havia um barqueiro que cruzava as pessoas de um lado do rio para o outro. Esse rio não tinha águas calmas, tinha ondulações. Certo dia estavam um advogado e uma professora no barco, junto ao barqueiro. No meio do rio o advogado, dotado de muita destreza com as palavras perguntou: 'Senhor barqueiro, o senhor conhece de leis?' E o barqueiro falou: 'Não, senhor. Eu não conheço nada de leis'. O advogado ficou triste e falou: 'Que pena, o senhor perdeu metade da sua vida'. A professora, também querendo ser sociável, entrou na conversa e perguntou ao barqueiro: 'Mas o senhor sabe ler e escrever?' E o barqueiro falou 'Não, senhora. Também não sei ler e escrever'. A professora também ficou triste e falou: 'Mas então o senhor perdeu a maior parte de sua vida'. Nisso uma onda bateu no barco, todos caíram na água e o barqueiro, vendo que o advogado e a professora estavam indo água abaixo e perguntou: 'Vocês sabem nadar?' E eles responderam: 'Não!' Então o barqueiro gritou: 'Que pena, vocês vão perder toda a sua vida'.

A anedota é para dizer que não existe conhecimento superior ou inferior. Naquele contexto, ali na água, o que valia era saber nadar, um conhecimento de necessidade básica daquele momento, que o barqueiro possuía. Você ter um título ou status social não significa que você é dono dos únicos conhecimentos válidos. No Brasil há muito desse tipo discriminação. Uma vez, no aeroporto de Los 
Angeles, encontrei uma brasileira riquíssima e passamos a conversar. Eu falei que o Brasil tem muita pobreza e ela disse, em um tom arrogante, que no Brasil não existe pobreza. Quer dizer, para os ricos, os pobres são invisíveis, mas os americanos quando vão ao Brasil, por exemplo, veem a pobreza claramente.

Então quando você pergunta por que Paulo Freire incomoda... Numa sociedade que diz que os mais humildes precisam ouvir e obedecer, Paulo Freire incomoda porque ele dá ouvidos, vez e voz para os "barqueiros da vida", para as pessoas mais humildes, buscando que possam se posicionar, abraçar a sua agency, o empoderamento de se ver como autores de suas próprias histórias. É bem claro que os discursos e narrativas dominantes do Brasil, no momento, novamente estão sendo exercidos pelos ricos e mais poderosos que se sentem justos enquanto os pobres são criminalizados por coisas miseráveis. Mas a gente precisa ver o Brasil dentro de um contexto mundial. Você, Mariana, vê o Brasil de dentro e eu vejo o Brasil de fora. Do ponto de vista metodológico não significa que um olhar é mais válido que o outro. A gente deve ter os dois olhares. Inclusive aqui nos Estados Unidos a professora Concha Delgado Gaitan fala que, na verdade, todos nós somos de fora, outsiders, ninguém é necessariamente um insider, uma pessoa que fala de dentro.

Mas observando quando você fala do contexto do Brasil, aqui nos Estados Unidos, semanas antes das eleições da Dilma o adversário sabia que ia perder a eleição e pediu ajuda aos americanos dizendo: 'Se vocês me ajudarem a ganhar eu dou petróleo brasileiro para vocês' e foi notícia nacional aqui. Então a gente não pode entender o Brasil só do ponto de vista de quem olha de dentro do Brasil, mas precisamos entender a problemática brasileira também com o olhar de fora. Eu sei que o Brasil sofreu uma intervenção do império norte-americano, o império do globo norte - e não se pode deixar de fora a Europa - porque o Brasil tem muitas riquezas. Mas esses grandes impérios só podem explorar esses países que ainda estão se desenvolvendo com a ajuda de quem está dentro do Brasil e aí está claro: o adversário da Dilma sabia que ia perder a eleição e ofereceu o petróleo para tentar ganhar de forma ilícita.

E não só isso. Eu fui professor na Universidade da Flórida e lá, juntamente com o cônsul brasileiro, descobri que três religiões estavam sendo exportadas para ○ Brasil em massas, com investimentos de milhões de dólares. E hoje a gente vê claramente que funcionou. Hoje o congresso brasileiro está dominado pelas três forças dos chamados BBB: Boi, Bala e Bíblia. E quando a gente fala do contexto brasileiro eu sinto a necessidade de falar que, de maneira geral, a população brasileira foi traída por seus próprios compatriotas. E a traição dói. O Brasil tem um número de mortes altíssimo, mas nem a metade das mortes aconteceriam se houvesse uma liderança competente, com interesse genuíno de ajudar a população brasileira. $O$ Brasil, hoje, tem um governo controlado pela classe 
A voz e vez dos barqueiros: Um diálogo crítico de reinvenção freireana frente aos desafios da atualidade

dominante brasileira e pelos interesses internacionais e comete um genocídio intencional, não acidental. Esse é um preço caro que o Brasil está pagando.

Então, Freire incomoda a burguesia principalmente, porque fala que seria muita ingenuidade nossa pensar que a classe dominante daria uma educação libertadora para os oprimidos, a partir da qual eles pudessem ver como estão sendo explorados. E Freire é colocado na bolsa com o pessoal do PT, da classe trabalhadora e mais humilde que ganhou voz, como se fosse traidor da burguesia. Aqui nos Estados Unidos também tem uma reação contrária a isso. Mas precisamos falar primeiro que o petróleo brasileiro está sendo roubado e eu acho que não se pode simplesmente culpar os interesses internacionais e estrangeiros, mas também perceber como alguns setores de dentro do Brasil colaboraram nesse ataque contra a soberania brasileira. Eu passei o ano de 2007 no Brasil em um ano sabático para escrever um livro e notei que existe na cultura brasileira uma tendência à corrupção, o chamado jeitinho brasileiro. Quando você fala de brasileiros nos Estados Unidos, por exemplo, as coisas são bem claras: os brasileiros que vem para cá reclamam, por exemplo, que as empregadas domésticas são caras porque precisam pagar bem, pagar os benefícios. Boston, Chicago, Flórida, Califórnia, são exemplos de lugares onde a comunidade brasileira é grandessíssima, e os brasileiros se destacam perante os cidadãos de outros países com o jeitinho brasileiro, que é um jogo de palavras porque demonstra uma subversão das regras. Na Disney de Orlando é preciso treinar os turistas brasileiros para não furar as filas e respeitar as outras pessoas. Existe sim essa ideia enraizada na identidade e no tecido social brasileiro, de ser espertalhão, passar os outros para trás e no final ainda culpar os vitimados, por serem "os bobos da corte".

O Brasil está na posição de hostage, refém do império do globo norte, refém das forças internacionais. A classe dominante brasileira é dona do poder legislativo, judiciário, governamental, político, das forças armadas, do poder midiático, das instituições educacionais, e instituições religiosas. Desde o golpe da Dilma, que foi um acordão, uma unificação do patriarcalismo com a supremacia branca e a elite capitalista predatória que a derrubou. E se você ver as fotos depois da saída forçada dela, você vê que só homens brancos estavam ao redor do presidente que se sentia orgulhoso em dizer que sua esposa era bela, recatada e do lar. E logo depois veio outro presidente que também é abusivo com as mulheres. É um horror uma pessoa no poder se demonstrar contra as minorias.

A população exigia uma grande luta contra a corrupção quando a Dilma era candidata. Eu observei que o povo exigiu com muita força que acabasse a corrupção e a Dilma falou que ia lutar contra a corrupção. Quando começou a apertar o jogo, o que a Dilma não entendeu foi que esse pessoal exigia a luta contra a corrupção para criminalizar os pobres, mas não os grandes. E ela foi considerada durona porque não podiam negociar. Ela foi a primeira mulher brasileira presidente. Os Estados Unidos chegaram perto, mas não conseguiram eleger uma mulher. É um fato inédito na história

Olhar de professor, Ponta Grossa, v. 24, p. I-22, e-16719.012, 2021.

Disponível em <https://revistas2.uepg.br/index.php/olhardeprofessor> 
brasileira. Quando a gente fala de Freire, do inédito viável, a Dilma e o Lula foram inéditos viáveis. Foi extraordinário na história do Brasil ver os barqueiros da vida, a classe trabalhadora representada nesse nível. E obviamente muitos saíram da pobreza, houve oportunidade de acesso à educação, à moradia, a vidas mais dignas. Mas a classe dominante não gostou, a intenção era criminalizar e aplicar rigor aos humildes e pobres, não aos ricos.

E aqui [nos Estados Unidos] a gente observa nas notícias internacionais pessoas com malas de dinheiro, drogas, a lava-jato aplicando lawfare ${ }^{8}$, com acusações falsas, baseadas em mentiras onde o próprio juiz é o acusador e o que julga. Isso é inaceitável. Então quando a gente fala de Freire já não entendemos mais como a pessoa em si, mas como parte de um movimento no qual houve uma grande revelação histórica. Por isso Paulo Feire incomoda e as forças reacionárias não querem o aceitar.

Quando você fala que estamos num contexto que re-clama Paulo Freire, por outro lado também vivemos um abuso na educação. Aqui nos Estados Unidos quatro corporações controlam todo o sistema educacional público e faturam milhões de dólares em cima das crianças por conta dos testes padronizados. Os professores já não dão aula para um currículo mais amplo, o teste é o currículo e se ensina a passar no teste. É uma educação triste, baseada na memorização e assim, ela não educa.

Uma grande fonte de sabedoria freireana, foi que ele nos relembrou sobre a raiz da palavra educação, proveniente do latim (exducere), o que significa trazer de dentro para fora. Na maioria das vezes nossa sociedade pensa que educação é levar de fora para dentro (educação de transmissão de conhecimento, bancária). Por isso andamos mal em muitas sociedades, forçando nossas crianças a estudar para provas estandardizadas/padronizadas e os professores acabam se institucionalizando a ensinar para prova, como se as provas fossem o currículo. Obviamente os alunos detestam estes tipos de pressões e logo em seguida esquecem o que estudaram. Sacrifica-se, assim, um currículo holístico, de empoderamento e de libertação social.

A importância de falar de Freire no contexto atual brasileiro está em entender a política brasileira de destruição dos recursos naturais, que faz assumir a posição de colonizado novamente. No pensamento de Freire isso é inaceitável porque todos nós temos direito a fazer história, sentir que podemos quebrar novas barreiras, construir novas oportunidades. E o inédito viável que Freire, o PT, - Lula e os 13 anos de um governo diferente constituíram foi uma plataforma de ajuda às classes mais pobres para que elas tivessem mais acesso ao poder aquisitivo. Sendo assim, a economia dá giro, as pessoas podem comprar mais e os produtores/companhias também tem mais lucros. As pessoas reclamam que tiveram de pagar impostos, mas também lucraram mais.

\footnotetext{
${ }^{8}$ Tanto no Brasil quando nos Estados Unidos quem tem dinheiro pode pagar um advogado, mas quem tem muito dinheiro compra o juiz.
}

Olhar de professor, Ponta Grossa, v. 24, p. I-22, e-16719.012, 2021.

Disponível em <https://revistas2.uepg.br/index.php/olhardeprofessor> 
A voz e vez dos barqueiros: Um diálogo crítico de reinvenção freireana frente aos desafios da atualidade

O Brasil também é refém da classe colonizadora dentro de um genocídio histórico dos povos originários e depois utilizou a escravidão na experiência da 'casa grande e senzala'. Mesmo que a gente rompa com essa teoria binária, vemos que as estruturas que oprimem as pessoas têm agentes que implementam a opressão e agentes que sofrem opressão. Quando se fala de Freire não deveríamos somente dar o enfoque ao oprimido, colocando a experiência do oprimido ao centro da análise acadêmica, mas também colocar a experiência do opressor ao centro dessa análise, pensar na pedagogia do opressor onde as pessoas que são privilegiadas possam ver seus privilégios. Quando eu falo de Freire, a nível internacional, as pessoas querem se colocar na posição de oprimidos, mas na verdade a gente também precisa se ver na posição de opressores.

Mariana: Você iniciou o comentário falando sobre a importância de lembrarmos da história de Paulo Freire e eu penso que essa importância está, também, na possibilidade de entendê-lo, de contextualizar seu pensamento e de perceber que ele ainda é relevante na atualidade. Um aspecto que eu acho importante mencionar é que, durante toda a sua história, Freire falou do diálogo, mas também esteve em constante diálogo com diferentes teóricos e diferentes contextos mundo afora. E esses diálogos faziam com que ele se reinventasse. Acho que isso contribui com o que você disse, ao mencionar que não entendemos mais Paulo Freire como uma pessoa em si, mas sim como um pensamento relacionado a um movimento no qual ele esteve inserido.

E esse movimento foi em prol de uma educação popular, conscientizadora, transformadora da realidade, libertadora, humanizadora. Foi um movimento revolucionário de educação, de revelação histórica, como você falou, porque promovia a equidade e qualidade da educação, buscando ultrapassar seus limites de acesso e alcance. Foi um movimento que ainda hoje se coloca presente nas realidades históricas dos oprimidos e suas diferentes lutas pela libertação. Como, por exemplo, na luta pela libertação da dominação dos poderes BBB que lideram o congresso, como você comentou. É uma libertação das narrativas do Brasil que continuam sendo construídas pelas elites, da história que continua sendo contada (desde os tempos de Cabral) pelos opressores, não pelos oprimidos. É uma luta pela construção de um caminho democrático e solidário que dá vez e voz ao povo, que permite que este se enxergue na história, olhe criticamente o espaço que lhe foi permitido ocupar até o momento e busque a transformação da realidade, a ocupação dos lugares de decisão e de poder. Por conta disso, o pensamento de Paulo Freire é, ainda hoje, revolucionário em tempos nos quais a educação, de modo geral, é ameaçada de diversas formas, tendo em vista que ela viabilizaria a consciência sociopolítica.

E o que torna essa concepção de educação revolucionária é que ela faz o convite para problematizarmos a realidade, ela questiona a realidade. Nesse sentido, complementando sua fala, podemos dizer que Paulo Freire incomoda porque nos pede para refletir e não seguir reproduzindo a

Olhar de professor, Ponta Grossa, v. 24, p. I-22, e-16719.012, 2021.

Disponível em <https://revistas2.uepg.br/index.php/olhardeprofessor> 
lógica social colonizadora e opressora. Ele nos dá a possibilidade de rompermos com essa lógica binária 'opressor e oprimido', que você também comentou. Pensando nas relações opressoras e lembrando que você também disse que é preciso dar nome aos sistemas opressores, gostaria de pedir para você falar um pouco mais sobre dois dos sistemas opressores existentes, sobre os quais você brevemente já abordou e que está entre seus temas de estudo: a questão de gênero e a questão do racismo.

César: Quando você pede para falarmos sobre a questão de gênero, o patriarcalismo não é essencialmente um problema da mulher. $O$ patriarcalismo é essencialmente um problema do homem que objetifica a mulher e a mulher sofre a consequência disso. Obviamente algumas mulheres internalizam isso. Ocorre o mesmo também com a questão da branquitude: o problema da supremacia branca é essencialmente um problema do branco que se aproveita dos não brancos e estes sofrem a consequência dessa construção social de superioridade. A história foi escrita pelos brancos, os colonizadores europeus e, por isso, hoje eu vejo que é muito mais efetivo quando um branco fala sobre o racismo, por exemplo. Do mesmo modo, quando um homem confronta outro homem sobre o patriarcalismo se faz uma pedagogia muito mais efetiva e fundamental.

Dadas as nossas características físicas, eu acho importante que a gente possa fazer uma autocrítica de nós mesmos. Quando eu saí da UCLA eu tomei consciência política das minhas características enquanto homem branco, consciência da política de gênero, étnico-racial e, apesar de sempre ter sonhado em voltar para o Brasil eu procurei trabalho nos Estados Unidos e acabei ficando por aqui. E eu pensei 'como eu posso ser mais efetivo, sabendo que trago comigo dois privilégios como homem e como branco?'. E descobri que eu poderia trabalhar em solidariedade com os que são mais oprimidos. Aqui nos Estados Unidos claramente as mulheres negras são os grupos mais oprimidos, depois tem os latinos, os indígenas, os asiáticos... Os não brancos. Eu pensei que como homem branco, desconstruindo estes privilégios, eu poderia trabalhar em solidariedade com esses grupos.

Quando eu olho para a América Latina, ao usar dados científicos, há cerca de 75 milhões de mulheres negras na América Latina e poucas delas ocupam cargos de poder onde se podem construir políticas que façam justiça a esses grupos. Ter consciência das políticas de gênero, é fundamental. É importante que a gente conheça as políticas sociais, de gênero, étnico-raciais. Porque, do contrário, apoiamos os nossos próprios opressores. Já se passaram 20 anos da minha formação enquanto doutor em educação e eu sinto que fui efetivo, que especialmente grupos mais oprimidos se sentem empoderados nas minhas salas de aula.

Mariana: Realmente nós precisamos fazer a desconstrução de um pensamento que está enraizado em nossa sociedade, precisamos desaprender algumas ideias que acabam sendo formas de opressão e estão internalizadas. Concordo com você quando fala que a desconstrução é muito mais efetiva quando feita de dentro dos próprios grupos e, para isso, também precisamos nadar contra a 
A voz e vez dos barqueiros: Um diálogo crítico de reinvenção freireana frente aos desafios da atualidade corrente porque, muitas vezes, a realidade não permite, não viabiliza a mudança de pensamento e de atitude. E a reflexão crítica constante que Paulo Freire nos inspira, se faz muito importante neste momento, para essas desconstruções de pensamento que precisam ser feitas em todos os espaços desde os mais simples e cotidianos às mais complexas organizações. Os chamados de "grupos minoritários" precisam estar em todos os lugares ocupando espaços de gestão, porque isso contribuiria com a desconstrução de ideias opressoras que estão enraizadas. Falando da ocupação de diferentes espaços, a universidade, por exemplo, ainda me parece ser um espaço de certo modo, uniforme, que não propicia o contato com a diversidade de "mundos" que temos no nosso mundo. Aqui é importante lembrar que não estou generalizando, mas não vejo uma grande diversidade.

Outro aspecto que contribuiria com essa desconstrução é justamente a conscientização sobre o quanto estão radicadas em nosso cotidiano as ideias de que homens e mulheres tem afazeres diferentes, de que brancos e não brancos ocupam espaços distintos ou de que certa camada social tem acesso somente a certo tipo de cultura, por exemplo. É preciso refletir cada vez mais sobre o quanto os modos de falar, de agir e de pensar são opressores. E essa reflexão pode libertar as pessoas das amarras dos costumes da sociedade e das suas ações reflexas e não reflexivas que permeiam desde o ambiente em que vivemos até o nosso olhar sobre quais são os estereótipos das pessoas nas quais mais se confia para gerir assuntos importantes, ou quem as pessoas mais colocam em cargos de gestão, etc. Nesse sentido, penso na importância de uma pedagogia que desconstrua estereótipos opressivos sejam eles de gênero, de raça ou de classe social porque, se as pessoas são educadas especialmente pelo exemplo - que, em geral, reproduz diferentes formas de opressão - elas também podem ser educadas para a reflexão crítica sobre a realidade, para conscientizarem-se das pequenas e grandes opressões que ocorrem ao seu redor, para transformarem radicalmente seu modo de pensar, seu modo de agir e, assim, transformarem a realidade.

César: Essa problemática é muito vigente no Brasil, então quando as pessoas oprimidas leem Freire e se dão conta dos conceitos fundamentais eles ficam deslumbrados e veem uma resposta para suas inquietudes. Agora, quando pessoas que tem muitos privilégios leem Freire, muitos deles dão uma pincelada e escolhem alguns conceitos, resumindo Freire a algumas questões, ou buscam se ver como oprimidos. Para que a gente possa reinventar Freire a gente precisa estudar e articular bem as hegemonias que nos afetam. Nesse período de pandemia fica bem claro quão selvagem e predatório pode ser esse sistema que tenta aniquilar os mais vulneráveis e quem são as forças que veem esses grupos como invisíveis ou que silenciam estes grupos. Quando se fala de Freire precisamos ter a mente aberta para ter conversas difíceis e essas conversas fazem parte da educação. Como Freire falava, a educação deve ser capaz de denunciar e também de anunciar. Oxalá não precisarmos falar das injustiças, se a nossa sociedade fosse justa. Mas como existe muita injustiça, precisamos ter essas 
conversas difíceis. Ao falar da educação libertadora fazendo parte de um grupo oprimido, você fala de uma pedagogia do oprimido. Se você não está em um grupo oprimido você pode trabalhar em solidariedade a ele.

E quando se fala de Freire a gente precisa tocar nessa ferida. E é bem evidente que colocar o dedo na ferida incomoda. Por isso Paulo Freire incomoda. Porque se o aplicarmos, depois de perpassarmos seu lado bonito, precisamos dar nome às problemáticas, aos sistemas hegemônicos opressivos. É uma conversa difícil de se ter, mas a gente precisa ter. Precisaríamos equalizar o campo do jogo para sairmos de igual para igual. Todos precisariam ter um acesso à alimentação, à educação igual, por exemplo. E aí depois a gente poderia dizer que tal pessoa teve mais destreza, se destacou mais e outro não. Antes todos nós devemos ter acesso à igualdade social, a uma melhor qualidade de vida.

Quando se fala da importância de defender a qualidade da democracia, que ○ Brasil está a ponto de perder, a gente precisa de pessoas que tenham acesso à qualidade de educação. A qualidade da democracia depende da qualidade da educação. A gente observa claramente esses países que tem democracias fantásticas, países nórdicos na Europa, até mesmo o Canadá, Nova Zelândia, Finlândia, Holanda, nos quais a democracia funciona porque não se deixa que os ricos usem medidas predatórias para usar e abusar dos demais. A democracia tem que ser protegida com unhas e dentes porque é um dos melhores sistemas sociais políticos e econômicos do mundo. É onde todos podem participar e ter voz, mas ela depende da qualidade da educação. Então Freire tinha razão: a educação é revolucionária e transformadora quando tem qualidade, quando dá acesso a um pensamento crítico e criativo para a resolução de problemas (problem-solving) e quando os alunos podem tomar as rédeas de suas próprias experiências educacionais.

Mariana: Com sua fala, lembro de uma frase de Freire: "se a educação sozinha não transforma a sociedade, sem ela tampouco a sociedade muda”. Ele queria dizer que só a educação, sem ação, sem práxis, não transforma a realidade. Mas essa transformação é possível, e realizada quando as pessoas são educadas, são conscientes, críticas, criativas e humanizadas. Uma educação problematizadora, conscientizadora, humanizadora e de qualidade faz com que as pessoas sejam conscientes de seus problemas (dos problemas coletivos, da sociedade) e, depois, busquem criar soluções para eles. Uma educação problematizadora faz com que as pessoas sejam conscientes de seus direitos e, depois, busquem lutar por eles. E, por isso, essa educação de qualidade seria um ponto propulsor para colocar em prática a democracia, como você bem disse. Para que essa educação democratizadora ocorra, assim como o pensamento freireano, como um todo, realmente é preciso nomear as problemáticas, pensar as formas de dominação que elas envolvem, perceber o quanto nossa realidade é desigual e observar 
A voz e vez dos barqueiros: Um diálogo crítico de reinvenção freireana frente aos desafios da atualidade as situações opressoras nas quais estamos imersos para tentar mudá-las. E essa mudança, da qual já falamos outras vezes, seria também um ato de amor ao mundo e ao próximo.

Pelo que sei, você considera importante o conceito de amorosidade e eu penso que, se ele fosse presente na sociedade seria muito mais possível, muito mais fácil que essa transformação ocorresse e que não houvessem mais relações de opressão, de dominação e de desumanização. Isso porque a amorosidade em Freire se coloca junto do compromisso com o outro, com a libertação do outro, o que faz com que amar seja um ato de coragem. Da mesma forma, ele diz que o amor, a amorosidade é característica fundamental para o diálogo. Resumindo, lembro que Freire explica que o diálogo é o encontro amoroso entre as pessoas que pronunciam o mundo, ○ transformam e $\circ$ humanizam. Por meio do amor pelo mundo e pelo próximo se dá a transformação e a humanização das pessoas. Em 202I Paulo Freire completaria 100 anos, e a busca pela humanização, pela qual perpassa o amor, é uma forma de manter vivo seu legado. A amorosidade é uma característica importante que poderia contribuir para a realização da democracia, especialmente na atualidade porque nela perpassam muitos discursos de ódio e medo. Ser amoroso seria uma forma de quebra dessas ideias. Nesse sentido, lembro que você já falou sobre o conceito de amorosidade como uma plataforma revolucionária para a atualidade e gostaria que, para finalizar nosso diálogo, você comentasse mais sobre isso.

César: São poucos os que se atrevem a falar do amor na educação, por isso a importância de mencionarmos isso. A ideia de amor, aqui nos Estados Unidos, é influenciada pela versão de Hollywood, é uma ideia de amor romântico, amor apaixonado e Freire não necessariamente quis falar sobre isso. Aqui as pessoas falam mais de compaixão e tolerância, mas essa ideia de amor freireano são poucos que articulam. Nel Noddings, por exemplo escreve sobre Caring education, uma educação da educação carinhosa, do cuidado do outro.

Mas, na entrevista que mencionei que fiz com Paulo Freire, ele me disse que trabalhava para que a nossa sociedade fosse menos feia, menos injusta e que as pessoas fossem capazes de amar. Freire se referiu ao amor como uma experiência revolucionária, onde as pessoas pudessem esperançar (ato de antecipar o que aspira - inédito viável), contemplar música, arte, poesia e ser mais felizes. Ele disse que nós vivemos em uma sociedade que tem muitas diferenças, mas também muitas similaridades e, por isso, precisamos aprender a trabalhar com essas diferenças. Se fizermos isso, seremos capazes de construir um mundo onde possamos viver em solidariedade. E quando se fala de amor, no sentido de Freire, falamos da importância de criarmos espaços na sociedade onde as pessoas podem ser o que elas são. Então, falar do amor no sentido freireano não tem nada muito romântico nem muito apaixonado, mas um sentido concreto e objetivo que entende o amor como única solução contra o discurso do ódio e que visa que a gente possa viver melhor um com os outros. Se a gente não é capaz de amar a si mesmo e amar ao outro, que significado tem a vida, não é? 
A ideia freiriana de aprender a ser sujeito da própria história mudou minha vida. Eu não me via como agente histórico. Assim como muitos barqueiros da vida aprendi que minhas experiências, como filho de agricultores, também são válidas, merecem atenção e ao transformá-las fui ganhando voz e vez. Essas experiências se transformam em fonte de conhecimento e quando colocadas a prova podem ser fontes de sabedoria. $O$ sim-bólico, que unifica e levanta o espirito das pessoas é de grande valor e esperança para a humanidade, mas o dia-bólico, que divide e carrega trevas e desesperanças - nas quais vivemos hoje, em meio a pandemia e as lideranças governamentais criminosas - acaba por destruir o tecido social (BOFF, 20I0). Neste contexto a falta de consciência crítica, da qual Freire falava, pode custar a vida das pessoas. A educação pode custar caro e ser sacrificante, mas a ignorância é muito mais cara e dispendiosa. Como já dizia Leonardo Boff (2010): a galinha vê curto e somente escarva ao seu redor, mas a águia vê um horizonte e o contexto mais amplo. A consciência crítica requer esse olhar amplificado que analisa os fatos e aplica rigor cientifico para ajudar a desenvolver o discernimento, muito necessário em sociedades democráticas, para sobreviver e viver melhor.

\section{Referências}

BOFF, L. O despertar da águia: $O$ dia-bólico e o sim-bólico na construção da realidade. 22. ed. Petrópolis: Vozes, 2010.

FREIRE, P. À sombra desta mangueira. 5. ed. São Paulo: Olho d'água, $200 \mathrm{I}$.

FREIRE, P.; MACEDO, D. Alfabetização: leitura do mundo leitura da palavra. Rio de Janeiro: Paz e Terra Ltda., 1994.

FREIRE, P. Pedagogia do oprimido. Rio de Janeiro: Paz e Terra, 2005.

MULLER, A. J.; ROSSATTO, C. A. Quality of education distinctive multi-dimensional trends: the real and viable transnational prospects for Brazil and United States' higher education. American Journal of Educational Research, Newark, v. 4, n. 17, nov. 2016. Disponível em: http://www.sciepub.com/education/content/4/I7. Acesso em: 8 set. 2020.

ROSSATTO, C. A. Social transformation and "popular schooling" in Brazil. Childhood Education, Londres, $\quad$ v. $77, \quad$ n. $6, \quad$ p. 367-374, 200I. Disponível em: https://www.tandfonline.com/doi/abs/I0.1080/00094056.200I .I052I672?journalCode=uced20.

Acesso em: I set. 2020.

ROSSATTO, C. A; SLATER, J.; FAIN, S. (orgs). The Freirean Legacy: Educating for Social Justice. New York, NY: Peter Lang Publishing, Inc., 2002.

ROSSATTO, C. A. Engaging Paulo Freire's Pedagogy of Possibility: From Blind to Transformative Optimism. Boulder, Colorado: Rowman \& Littlefield Publisher, Inc., 2005. 
ROSSATTO, C. A.; ALLEN, R.L.; PRUYN, M. (orgs.). Reinventing Critical Pedagogy: Widening the Circle of Anti-Oppression Education. Boulder, Colorado: Rowman \& Littlefield Publisher, Inc, 2006.

ROSSATTO, C. A.; PARASKEVA, J.; ALLEN, R. L. (orgs.) Reinventar a Pedagogia Crítica. Lisboa, Portugal: Edições Pedago, LDA, 2005.

Recebido em: 24 de agosto de 2020.

Versão corrigida recebida em: 10 de novembro de 2020.

Aceito em: 07 de dezembro de 2020.

Publicado online em: 12 de março de 202I.

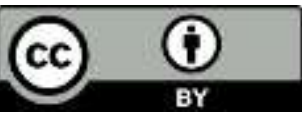

